\title{
Microbial biodiversity in arable soils is affected by agricultural practices**
}

\author{
Agnieszka Wolińska ${ }^{*}$, Dorota Górniak ${ }^{2}$, Urszula Zielenkiewicz³ ${ }^{3}$ Agata Goryluk-Salmonowicz ${ }^{4}$, \\ Agnieszka Kuźniar ${ }^{1}$, Zofia Stępniewska ${ }^{1}$, and Mieczysław Błaszczyk ${ }^{4}$
${ }^{1}$ Department of Biochemistry and Environmental Chemistry, The John Paul II Catholic University of Lublin, Konstantynów 1i, 20-708 Lublin, Poland
${ }^{2}$ Faculty of Biology and Biotechnology, Department of Microbiology, University of Warmia and Mazury in Olsztyn, Oczapowskiego 1a, 10-719 Olsztyn, Poland \\ ${ }^{3}$ Department of Microbial Biochemistry, Institute of Biochemistry and Biophysics PAS, Pawińskiego 5a, 02-206 Warsaw, Poland \\ ${ }^{4}$ Department of Microbial Biology, Warsaw University of Life Sciences, Nowoursynowska 159, 02-776 Warsaw, Poland
}

Received September 14, 2016; accepted February 1, 2017

A b s t r a c t. The aim of the study was to examine the differences in microbial community structure as a result of agricultural practices. Sixteen samples of cultivated and the same number of non-cultivated soils were selected. Gel bands were identified using the GelCompar software to create the presence-absence matrix, where each band represented a bacterial operational taxonomic unit. The data were used for principal-component analysis and additionally, the ShannonWeaver index of general diversity, Simpson index of dominance and Simpson index of diversity were calculated. Denaturing gradient gel electrophoresis profiles clearly indicated differentiation of tested samples into two clusters: cultivated and non-cultivated soils. Greater numbers of dominant operational taxonomic units (65) in non-cultivated soils were noted compared to cultivated soils (47 operational taxonomic units). This implies that there was a reduction of dominant bacterial operational taxonomic units by nearly $30 \%$ in cultivated soils. Simpson dominance index expressing the number of species weighted by their abundance amounted to 1.22 in cultivated soils, whereas a 3-fold higher value (3.38) was observed in non-cultivated soils. Land-use practices seemed to be a important factors affected on biodiversity, because more than soil type determined the clustering into groups.

K e y w o r d s: DGGE, 16S rRNA gene, Simpson diversity, bacterial communities, arable soils

\section{INTRODUCTION}

Understanding of the main drivers influencing diversity of microbial species in soils is important as it can be related to agricultural crop yields (Lopes et al., 2011). The European Environmental Agency (EEA), the Commission

\footnotetext{
*Corresponding author e-mail: awolin@kul.pl

**This work was partly funded by the National Science Centre (Poland), grant No. DEC-2013/09/D/NZ9/02482, 2014-2016.
}

of the European Communities (EC), European Union (EU), Biodiversity Strategy to 2020 and European project ENVASSO promote the protection strategy of microbial communities, especially in the arable soils with description of soil microbiological degradation state. It is known, that agricultural types of soil are usually biologically degraded (Wolińska et al., 2014), which is confirmed by the fact that arable soils are less biodiverse (Torsvik et al., 1998), in comparison to natural soils (typically $>1000$ species per g). Soil biodiversity degradation has been estimated to affect $16-40 \%$ of terrestrial areas (Girvan et al., 2003). Soil contains an intricate network of microbes and plants in a heterogeneous solid medium in which both chemical, physical and biological conditions vary at the molecular scale (Arias et al., 2005). Traditionally, soil quality has been directly related to its productivity, but more recently it has been regarded as the soil capacity to sustain biological and environmental features, and to promote plant and animal health within ecosystems (Girvan et al., 2003). The productivity of agricultural systems is known to depend greatly upon the functional processes of soil microbial communities (Girvan et al., 2003). Arias et al. (2005) emphasized that soil health provides an overall picture of soil functionality, whereas microbial diversity is intimately related to soil structure, and the way of land use and soil functions. A study of Kuffner et al. (2004) demonstrated that soil microorganisms are sensitive to anthropogenic disturbances, in particular to agricultural activities, and also

(C) 2017 Institute of Agrophysics, Polish Academy of Sciences 
showed that the composition of the microbiota not only can give an information about the state but also about the previous history of the soil ecosystem.

Biodiversity has been defined as the range of significantly different types of organisms and their relative abundance in an assemblage or community (Torsvik et al., 1998). Species diversity consists of two components: (a) species richness and (b) species evenness and/or distribution (Torsvik et al., 1998). Additionally, Louzpone et al. (2007) have distinguished diversity within each sample ( $\alpha$ diversity) and the portioning of biological diversity among environments ( $\beta$ diversity). The latter could be further divided into qualitative measure, which is connected to the availability of data to compare community components, and quantitative measures, which take into account relative abundances of each organism type (Louzpone et al., 2007).

Community level fingerprinting methods, like denaturing gradient gel electrophoresis (DGGE) introduced by Muyzer et al. (1993) have distinct advantages over culture based assays, particularly in relation to describing the numerically dominant fraction of the community, a large component of which may not be conveniently cultured (Kuffner et al., 2004). Only a minor fraction of soil bacteria, usually estimated at $1 \%$ of the total number of cells observed by direct counting, could be cultured on laboratory artificial media (Torsvik et al., 1998), which is why the techniques such as DGGE can be superior for studying microbial diversity in the field and should be recommended for the microbial community studies. All prokaryotes have 16S rRNA genes whose average length is about $1500 \mathrm{bp}$ (Shao-Qiang et al., 2012). The microbial diversity can be estimated from the number of 16S rRNA gene sequence similarity groups, i.e. the number of DNA bands on the DGGE gel (Shao-Qiang et al., 2012). Consequently, DGGE provides an estimate of the diversity within a community, based on the number of amplicons of each type, representing an operational taxonomic units (OTUs), assumed to be an equivalent to a bacterial genotype (Arias et al., 2005; Kuffner et al., 2004; Shao-Qiang et al., 2012). However, rare microorganisms which are ecologically relevant may not be detected using a universal approach (Kuffner et al., 2004). Polymerase chain reaction (PCR) in combination with DGGE can provide information about presence/ absence but not about abundance of particular species due to 'qualitative nature' of PCR (Petersen and Dahllöf, 2005). Nonetheless, those techniques are necessary to understand ecological effects on biodiversity (Petersen and Dahllöf, 2005). Casamayor et al. (2000) reported that to be visible as a band on the gel, a species should represent at least $1 \%$ of the soil microbial community. The analysis of the soil microbiological degradation state is systematically conducted by many countries of the European Union, but this is the first such study undertaken in Poland.
Our major goal was to compare the bacterial community structure between agricultural and non-cultivated (natural) soils in order to find out the degree of microbial community degradation, caused by intensive agricultural practices. For the structural diversity determination of dominating populations PCR-DGGE technique was applied. Principal components analysis (PCA) and canonical correspondence analysis (CCA) for investigated soil bacterial communities and environmental factors effect based on DGGE profiles were also demonstrated.

\section{MATERIALS AND METHODS}

Study was performed in south-east part of Poland, in Lubelskie province $\left(51^{\circ} 13^{\prime} \mathrm{N} 22^{\circ} 54^{\prime} \mathrm{E}\right)$ which is characterized by the great diversity of soil types and is one of the largest and most important agricultural areas in Poland where all Polish dominant soil units are present. Sixteen soil samples which were agriculturally exploited (cultivated $-C$ ) and the same number of soils not agriculturally exploited (non-cultivated - NC) were studied. Soil materials have been selected on the basis of earlier work for the typological soil recognition performed in 1991 within the framework of the Bank of Soil Samples (BSS) belonging to the Institute of Agrophysics PAS in Lublin (Bieganowski et al., 2013). Consequently, the fact of soils cultivation is documented since 1991 (from the foundation of BSS). Precise localization of the samples catalogued in the BSS created a possibility of the precise return to the sampling place (Gliński et al., 1991).

The cultivated soils were sampled during spring season (April 2014) from non ploughed places (Wolińska et al., 2014), according BSS locations. We consciously decided to take samples in spring season before the time when vegetation completely started and when ploughing is applied in order to avoid direct perturbations caused by tillage that affects on microorganisms destruction. The same time control samples were taken from non agriculturally cultivated and non forested sites (covering at least 1 ha area), located in close neighbouring to cultivated soils and belonging to the same soil type (i.e. non cultivated from years fallow lands or grasslands). In our study we focused on demonstrating those differences that resulted from long-term soil cultivation and soil 'fatigue' as those differentiation in microbial communities may have resulted from soil cultivation or the lack of cultivation for many years (20-40 years) of grasslands and/or fallow lands moved. We did not focus on the well-recognized and well described by other researchers effect of direct ploughing on soil microbial community but rather we point to those differences which do not result from direct tillage impact. Description of the fields differed by crop type and control site is presented in Table 1. 
T a b l e 1. Location of agricultural soils and description of control sites (Lublin region)

\begin{tabular}{|c|c|c|c|c|c|}
\hline $\begin{array}{l}\text { Soil } \\
\text { No. }\end{array}$ & Type of soil (FAO) & Crop type & Site & $\begin{array}{l}\text { Geographic } \\
\text { coordinates }\end{array}$ & Control sites \\
\hline 1 & Albic Luvisol & Oat & Dęba & $\begin{array}{l}22^{\circ} 10^{\prime} 17.7^{\prime \prime} \\
51^{\circ} 26^{\prime} 24.6^{\prime \prime}\end{array}$ & $\begin{array}{l}30 \text { year old meadow planted with fruit } \\
\text { trees }\end{array}$ \\
\hline 2 & Albic Luvisol & Triticale & Pryszczowa Góra & $\begin{array}{l}22^{\circ} 27^{\prime} 10.33^{\prime \prime} \\
51^{\circ} 24^{\prime} 30.8^{\prime \prime}\end{array}$ & 20 year old woodlots with birches \\
\hline 3 & Albic Luvisol & Wheat & Niemce & $\begin{array}{l}22^{\circ} 36^{\prime} 51.88^{\prime \prime} \\
51^{\circ} 21^{\prime} 27.0^{\prime \prime}\end{array}$ & 50 year old meadow (mowed once a year) \\
\hline 4 & Haplic Luvisols & Triticale & Klementowice & $\begin{array}{l}22^{\circ} 06^{\prime} 54.2^{\prime \prime} \\
51^{\circ} 21^{\prime} 52.2^{\prime \prime}\end{array}$ & Unmoved meadow, wasteland \\
\hline 5 & Brunic Arenosols & Oat & Łany & $\begin{array}{l}22^{\circ} 15^{\prime} 19.0^{\prime \prime} \\
51^{\circ} 23^{\prime} 00.9^{\prime \prime}\end{array}$ & 20 year old field-woodlots \\
\hline 6 & Brunic Arenosols & Oat & Markuszów & $\begin{array}{l}22^{\circ} 15^{\prime} 55.5^{\prime \prime} \\
51^{\circ} 23^{\prime} 10.9^{\prime \prime}\end{array}$ & 20 year old field-woodlots \\
\hline 7 & Haplic Luvisol & $\begin{array}{l}\text { Field prepared for } \\
\text { seeding }\end{array}$ & Rogalin & $\begin{array}{l}24^{\circ} 04^{\prime} 00.3{ }^{\prime \prime} \\
50^{\circ} 51^{\prime} 15.8^{\prime \prime}\end{array}$ & Meadow (mowed once a year) \\
\hline 8 & Haplic Luvisols & Triticale & Sady & $\begin{array}{l}23^{\circ} 22^{\prime} 52.4^{\prime \prime} \\
50^{\circ} 51^{\prime} 14.8^{\prime}\end{array}$ & Unmoved meadow, wasteland \\
\hline 9 & Haplic Luvisols & Strawberries & Chrząchówek & $\begin{array}{l}22^{\circ} 07^{\prime} 29.9^{\prime \prime} \\
51^{\circ} 25^{\prime} 50.5^{\prime}\end{array}$ & Unmoved meadow, wasteland \\
\hline 10 & Haplic Phaezoem & Triticale & Hostynne & $\begin{array}{l}50^{\circ} 44^{\prime} 48.3 \prime \\
23^{\circ} 42^{\prime} 56.6\end{array}$ & Meadow (mowed once a year) \\
\hline 11 & Mollic Gleysol & Colza & Pożóg Nowy & $\begin{array}{l}22^{\circ} 06^{\prime} 18.8^{\prime \prime} \\
51^{\circ} 22^{\prime} 48.0^{\prime \prime}\end{array}$ & 30 year old pine woodlots \\
\hline 12 & Mollic Gleysol & Wheat & Bałtów & $\begin{array}{l}22^{\circ} 01^{\prime} 25.5^{\prime \prime} \\
51^{\circ} 29^{\prime} 15.3 \prime\end{array}$ & 70 year old meadow (mowed once a year) \\
\hline 13 & Eutric Fluvisol & Oat & Kośmin & $\begin{array}{l}21^{\circ} 59 ' 10.1^{\prime \prime} \\
51^{\circ} 333^{\prime} 47.7^{\prime \prime}\end{array}$ & 15 year old meadow (mowed once a year) \\
\hline 14 & Eutric Histosol & Oat & Wólka Kątna & $\begin{array}{l}22^{\circ} 16^{\prime} 38.9^{\prime \prime} \\
51^{\circ} 25^{\prime} 27.3^{\prime \prime}\end{array}$ & 20 year old meadow (mowed once a year) \\
\hline 15 & Rendzina Leptosol & Celeries & Siedliszcze & $\begin{array}{l}23^{\circ} 10^{\prime} 58.3^{\prime \prime} \\
51^{\circ} 12^{\prime} 22.3^{\prime \prime}\end{array}$ & 40 year old meadow (mowed once a year) \\
\hline 16 & Rendzina Leptosol & Oat & Brzeziny & $\begin{array}{l}23^{\circ} 11^{\prime} 43.9^{\prime \prime} \\
51^{\circ} 12^{\prime} 10.8^{\prime \prime}\end{array}$ & Meadow (mowed once a year) \\
\hline
\end{tabular}

$10 \times 10 \mathrm{~m}^{2}$ were chosen for each of the 16 different areas of the sample sites characterized by the homogeneity of the vegetation cover (Table 1). Within these squares approx. 50 random soil samples were taken from the top layer $(0-20 \mathrm{~cm})$ using a $2.5 \mathrm{~cm}$ diameter auger. Single samples were combined and homogenized into one sample in order to receive the most representative soil material for each investigated site. In this manner, 16 samples for cultivated (C) and 16 samples for control sites (NC) were obtained.
Haplic Luvisols, Brunic Arenosols and Albic Luvisols are predominant soil types in Poland, occupying by $82 \%$ of the country, thus their share (nine soil samples) in the studied material was representative (Wolińska et al., 2014). Haplic Luvisols were represented by four soil samples (4C, 7C-9C), Albic Luvisols by three samples (1C-3C), while Brunic Arenosols by two samples (5C-6C). Mollic Gleysol and Rendzina Leptosol have also two representatives $(11 \mathrm{C}-12 \mathrm{C})$ and (15C-16C), respectively (Table 1). Haplic 
Phaeozem (10C), Eutric Fluvisol (13C) and Eutric Histosol (14C) were represented by single soil samples. Under laboratory conditions each sample was passed through a $2.0 \mathrm{~mm}$ sieve, to remove large pieces of rocks and plant material and stored at $4^{\circ} \mathrm{C}$ prior analysis (2-3 days).

Soil $\mathrm{pH}$ and redox potential (Eh) were determined in a 2:1 soil suspension in distilled water using a multifunctional potential meter pIONneer 65 (Radiometer Analytical S.A., France). Soil actual moisture was determined by a gravimetric method $\left(24 \mathrm{~h}, 105^{\circ} \mathrm{C}\right)$, whereas total carbon (TC) using an automatic carbon analyzer TOC- $\mathrm{V}_{\mathrm{CSH}} \mathrm{SSM}$ 5000A (Shimadzu, Japan) as described by Wolińska et al. (2014). The concentrations of soluble phosphorus $\left(\mathrm{P}-\mathrm{PO}_{4}{ }^{3}\right)$, nitrate $\left(\mathrm{N}^{-} \mathrm{NO}_{3}{ }^{-}\right)$, nitrite $\left(\mathrm{N}-\mathrm{NO}_{2}{ }^{-}\right)$and ammonium $\left(\mathrm{N}^{-\mathrm{NH}_{4}}{ }^{+}\right)$(were determined colorimetrically using Auto Analyser 3 System (Bran+Luebbe, Norderstedt, Germany). P- $\mathrm{PO}_{4}{ }^{3}$ was analysed with ammonium molybdate (Banach

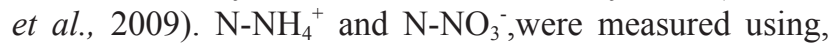
respectively, hydrazine sulphate and salicylate as a colour

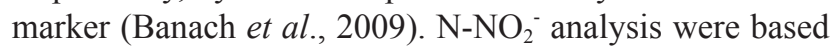
on the latter method excluding hydrazine sulphate. Obtained results have been expressed as $\mu \mathrm{g}$ per $\mathrm{g}$ of fresh soil. Each analysis was performed in triplicate.

Total DNA was isolated according to the modified procedure for soil samples as described by Tomczyk-Żak et al. (2013). In order to reduce the presence of humic substances and other soil impurities the crude total DNA was further purified by $\mathrm{CsCl}$ gradient centrifugation $(16 \mathrm{~h}$, $70000 \mathrm{rpm}, 20^{\circ} \mathrm{C}$; Sorvall WX Ultra ThermoScietific) as described by Sambrook et al. (1989). Two replicates of DNA extraction were made. Concentrations of the isolated DNA were assessed with NanoDrop spectrophotometer (ThermoScientific) after 10 times dilution.

To determine bacterial taxonomic diversity in the studied soils, a DGGE analysis of samples was performed. Dominant bacterial phylotypes were distinguished by DGGE analysis and electrophoresis performed with a D-Code Universal Mutation Detection System (BioRad Laboratories, USA). A 1-2 $\mu 1$ volume (roughly 5-10 ng diluted form) of each DNA was amplified by PCR mixture contained $5 \mu \mathrm{l}$ of $10 \times$ buffer, $6.0 \mu \mathrm{l}$ of $25 \mathrm{mM} \mathrm{MgCl}_{2}, 1.2 \mu 1$ of $20 \mathrm{mg} \mathrm{ml}^{-1}$ BSA, $0.4 \mu \mathrm{l}$ of $25 \mathrm{mM}$ dNTP, $0.5 \mu \mathrm{l}$ of $20 \mu \mathrm{M}$ in each primer, $0.2 \mu \mathrm{l}$ of $5 \mathrm{U} \mu 1^{-1}$ Taq DNA polymerase (all reagents from Sigma Aldrich Co.) and $35.2 \mu \mathrm{L}$ of PCR-grade water, in a total volume of $50 \mu \mathrm{l}$. The primers used were 341f with GC clamp (5'-GC- CC TAC GGG AGG CAG CAG-3') complementary to position 341-357 and 907r (CCG TCA ATT CMT TTG AGT TT) complementary to positions 926-907 Escherichia coli numbering (Muyzer et al., 1993, 1998). The PCR conditions have been previously described in Zdanowski et al. (2013). The samples were loaded in $6 \%$ acrylamide gels with a denaturing gradient of $35-70 \%$ (where $100 \%$ denaturant is $7 \mathrm{M}$ urea and $40 \%$ formamide). The same amount of DNA (40 ng) for each amplicons were loaded into the gel. The gels were run at $60 \mathrm{~V}$ for $15 \mathrm{~h}$ at $60^{\circ} \mathrm{C}$. The electrophoretic products were stained by gently agitating the gel for $30 \mathrm{~min}$ in $100 \mathrm{ml}$ of $1 \times$ TAE containing $5 \mu 1$ 1:10,000 commercial stock dilution of SYBR Gold nucleic acid stain (Invitrogen, Life Technologies, UK) in DMSO. DGGE banding patterns were visualized with UV transillumination and photographed using the Gel Doc 2000 gel documentation system (BioRad Laboratories, USA).

The bacterial community in each soil sample was compared by using DGGE fingerprinting. DGGE gel images were analyzed by Quantity One software in the GelDoc gel documentation system (BioRad Laboratories, USA). Gel bands were identified using GelCompar software to create the presence-absence matrix described by Crump and Hobbie (2005). Each band represents a bacterial OTU. The DNA bands were identified interactively, and the position and mass (intensity) of each band were determined. The data were used for principal-component analysis to evaluate differences between the DNA profiles. Qualitative PCA in which the presence but not the intensity of bands was used gave the best separation between different samples. The presence or absence of a band in each line was converted to binary matrix to access data for statistical analysis.

Dominant (well-defined) DGGE bands were excised using a scalpel blade and incubated overnight $\left(4^{\circ} \mathrm{C}\right)$ in sterile distilled water before they were re-amplified (Chong et al., 2009). The PCR products were purified (Clean up, GenoPlastBiochemicals) and ligated into the pTZ57R/T (ThermoFisher Scientific) following instructions of the manufacturer. The ligation products were transformed into Escherichia coli DH5 $\alpha$ using a InsTAclonePCR Cloning Kit (ThermoFisher Scientific) and cells were plated into an indicator agar which consisted of lysogeny broth (LB) medium supplemented with ampiciline $\left(100 \mathrm{mg} \mathrm{ml}^{-1}\right)$, X-Gal $(0.1 \mathrm{mM})$ and IPTG $(0.2 \mathrm{mM})$. White colonies of transformants were replated into LB with ampiciline and after incubation the plasmid DNA was isolated (Plasmid Miniprep DNA Purification Kit, Eurx). To confirm the presence of the insert, PCR with the $341 \mathrm{f}$ and $907 \mathrm{r}$ primers was performed as described earlier. Sequencing of positive clones was carried out at by ABI3730 Genetic Analyzer (Applied Biosystems) and then, sequences were compared to those deposited in the GenBank nucleotide database. Only sequences displaying $99-100 \%$ similarity are presented here.

The relative intensity data of the DNA bands from the bacterial communities were used to carry out the following analyses and calculations. PCA of the 16S rDNA gene band patterns was performed using the Canoco v. 4.5 statistical pack (ter Braak and Šmilauer, 2002) for Windows v. software. Microbiological data for each sample were analyzed with reference to the environmental background 'all other data'. Canonical correspondence analysis (CCA) 
triplots along the two main axes of variation for the bacterial structure parameters, main environmental variables and sampled sites was also conducted.

The Shannon-Weaver diversity index, H' (Shannon and Weaver, 1963) and Simpson index of dominance (D), (Simpson, 1949) were calculated from the quantity and relative intensities of bands present in each lane according to Vivas et al. (2009). The digital image was analyzed, and the similarity cluster analyses based on Complete Linkage algorithm were generated by Quantity One v. 4.62 (Bio-Rad) software to express the relatedness of bacterial communities as similarity clusters. Species rich- ness was determined as the number of bands resolved by PCR/DGGE in 1 sample lane. The similarity between the band patterns was calculated using the Dice coefficient and the clustering analysis was performed with the unweighted pair group method using arithmetic averages (UPGMA) for dendrogram construction using the STATISTICA version 10 (Stat-Soft) software package.

\section{RESULTS}

Land-use practices seemed to be a strong determinant $(p<0.05)$ of soil chemical features (Table 2$)$. As could be anticipated, agricultural soil exploitation was the reason

T a b l e 2. Chemical and biological characteristics of cultivated (C) and non-cultivated (NC) soils ( \pm SD)

\begin{tabular}{|c|c|c|c|c|c|c|c|c|}
\hline \multirow{2}{*}{$\begin{array}{l}\text { Soil } \\
\text { No. }\end{array}$} & \multirow{2}{*}{$\begin{array}{c}\text { Moisture (\%) } \\
(\mathrm{w} / \mathrm{w})\end{array}$} & \multirow{2}{*}{$\begin{array}{c}\mathrm{pH} \\
\left(\mathrm{H}_{2} \mathrm{O}\right)\end{array}$} & \multirow{2}{*}{$\begin{array}{c}\text { Eh } \\
(\mathrm{mV})\end{array}$} & \multirow{2}{*}{$\begin{array}{l}\mathrm{TC} \\
(\%)\end{array}$} & $\mathrm{N}-\mathrm{NH}_{4}^{+}$ & $\mathrm{N}-\mathrm{NO}_{3}^{-}$ & $\mathrm{N}-\mathrm{NO}_{2}^{-}$ & $\mathrm{P}-\mathrm{PO}_{4}{ }^{3-}$ \\
\hline & & & & & \multicolumn{4}{|c|}{$\left(\mu \mathrm{g} \mathrm{g}^{-1}\right)$} \\
\hline $1 \mathrm{C}$ & $8.20 \pm 0.20 \mathrm{a}$ & $5.23 \pm 0.06 a$ & $477.4 \pm 0.40 \mathrm{a}$ & $0.98 \pm 0.02 a$ & $0.01 \pm 0.006 a$ & $9.34 \pm 0.8 \mathrm{a}$ & $0.11 \pm 0.003 a$ & $2.56 \pm 0.04 a$ \\
\hline $1 \mathrm{NC}$ & $9.76 \pm 0.11 b$ & $6.27 \pm 0.005 c$ & $435.2 \pm 0.20 \mathrm{~d}$ & $1.76 \pm 0.12 \mathrm{~d}$ & $0.09 \pm 0.006 \mathrm{~d}$ & $1.68 \pm 0.014 \mathrm{~d}$ & $0.17 \pm 0.001 \mathrm{~b}$ & $1.77 \pm 0.03 \mathrm{~d}$ \\
\hline $2 \mathrm{C}$ & $9.30 \pm 0.10 \mathrm{a}$ & $4.66 \pm 0.02 a$ & $546.73 \pm 0.21 \mathrm{a}$ & $1.23 \pm 0.04 a$ & $0.02 \pm 0.001 \mathrm{a}$ & $7.37 \pm 0.05 a$ & $0.08 \pm 0.001 \mathrm{a}$ & $1.51 \pm 0.01 \mathrm{a}$ \\
\hline $2 \mathrm{NC}$ & $11.16 \pm 0.11 b$ & $5.02 \pm 0.02 b$ & $528.40 \pm 0.36 \mathrm{c}$ & $1.40 \pm 0.05 b$ & $0.04 \pm 0.014 b$ & $5.84 \pm 0.03 \mathrm{c}$ & $0.10 \pm 0.001 \mathrm{a}$ & $1.01 \pm 0.01 \mathrm{c}$ \\
\hline $3 \mathrm{C}$ & $10.22 \pm 0.03 a$ & $4.78 \pm 0.02 a$ & $535.7 \pm 0.30 \mathrm{a}$ & $1.24 \pm 0.04 a$ & $0.01 \pm 0.001 a$ & $53.32 \pm 0.52 a$ & $0.05 \pm 0.005 a$ & $19.6 \pm 0.98 a$ \\
\hline $3 \mathrm{NC}$ & $9.13 \pm 0.05 b$ & $6.22 \pm 0.09 \mathrm{~d}$ & $452.86 \pm 0.11 \mathrm{~d}$ & $1.79 \pm 0.14 \mathrm{c}$ & $0.06 \pm 0.006 \mathrm{~d}$ & $3.58 \pm 0.09 \mathrm{~d}$ & $0.42 \pm 0.005 \mathrm{~d}$ & $1.16 \pm 0.05 \mathrm{~d}$ \\
\hline $4 \mathrm{C}$ & $12.56 \pm 0.06 \mathrm{a}$ & $6.98 \pm 0.02 a$ & $450.03 \pm 0.32 a$ & $1.96 \pm 0.05 a$ & $0.43 \pm 0.006 a$ & $18.25 \pm 0.06 \mathrm{a}$ & $0.10 \pm 0.004 a$ & $12.9 \pm 0.04 a$ \\
\hline $4 \mathrm{NC}$ & $13.50 \pm 0.10 \mathrm{~b}$ & $7.08 \pm 0.06 \mathrm{a}$ & $419.20 \pm 1.11 \mathrm{~d}$ & $2.52 \pm 0.14 \mathrm{c}$ & $0.48 \pm 0.008 \mathrm{~b}$ & $7.57 \pm 0.32 \mathrm{~d}$ & $0.53 \pm 0.003 \mathrm{~d}$ & $5.9 \pm 0.03 d$ \\
\hline $5 C$ & $6.60 \pm 0.10 a$ & $5.45 \pm 0.04 a$ & $470.20 \pm 17.75 a$ & $1.01 \pm 0.04 a$ & $0.07 \pm 0.006 a$ & $25.53 \pm 0.18 a$ & $0.12 \pm 0.001 \mathrm{a}$ & $6.88 \pm 0.01 \mathrm{a}$ \\
\hline $5 \mathrm{NC}$ & $8.63 \pm 0.15 c$ & $5.58 \pm 0.04 b$ & $396.13 \pm 0.23 \mathrm{~d}$ & $2.06 \pm 0.19 \mathrm{~d}$ & $0.69 \pm 0.009 \mathrm{~d}$ & $10.18 \pm 0.14 \mathrm{~d}$ & $0.21 \pm 0.002 \mathrm{~d}$ & $3.52 \pm 0.09 \mathrm{~d}$ \\
\hline $6 C$ & $9.23 \pm 0.06 a$ & $4.78 \pm 0.006 a$ & $480.60 \pm 0.18 a$ & $0.83 \pm 0.09 a$ & $0.01 \pm 0.007 a$ & $20.26 \pm 0.07 a$ & $0.09 \pm 0.004 a$ & $4.01 \pm 0.01 \mathrm{a}$ \\
\hline $6 \mathrm{NC}$ & $8.63 \pm 0.15 b$ & $5.58 \pm 0.04 \mathrm{c}$ & $396.13 \pm 0.23 d$ & $2.06 \pm 0.19 \mathrm{~d}$ & $0.69 \pm 0.009 \mathrm{~d}$ & $10.18 \pm 0.14 \mathrm{~d}$ & $0.21 \pm 0.002 \mathrm{~d}$ & $3.52 \pm 0.09 b$ \\
\hline $7 \mathrm{C}$ & $12.13 \pm 0.15 a$ & $.06 a$ & $\mathbf{a}$ & $\mathbf{a}$ & $1 \mathrm{a}$ & $\pm 0.04 \mathrm{a}$ & $0.005 a$ & $4.61 \pm 0$. \\
\hline $7 \mathrm{NC}$ & $12.76 \pm 0.11 \mathrm{~b}$ & $6.99 \pm 0.03 \mathrm{a}$ & $400.66 \pm 0.15 a$ & $3.49 \pm 0.11 \mathrm{~d}$ & $0.41 \pm 0.008 \mathrm{~d}$ & $5.41 \pm 0.14 d$ & $0.87 \pm 0.003 \mathrm{~d}$ & $3.85 \pm 0.03 \mathrm{~d}$ \\
\hline $8 C$ & $19.00 \pm 0.17 \mathrm{a}$ & $5.96 \pm 0.12 a$ & $461.10 \pm 0.17 a$ & $0.96 \pm 0.11 \mathrm{a}$ & $0.36 \pm 0.02 a$ & $17.35 \pm 0.03 a$ & $0.12 \pm 0.002 a$ & $6.81 \pm 0.02 a$ \\
\hline $8 \mathrm{NC}$ & $20.26 \pm 0.63 c$ & $6.06 \pm 0.01 \mathrm{a}$ & $409.23 \pm 0.25 \mathrm{c}$ & $2.68 \pm 0.07 d$ & $2.61 \pm 0.04 d$ & $11.07 \pm 0.05 \mathrm{~d}$ & $0.24 \pm 0.02 \mathrm{c}$ & $2.94 \pm 0.03 \mathrm{~d}$ \\
\hline $9 \mathrm{C}$ & $5.66 \pm 0.11 \mathrm{a}$ & $5.13 \pm 0.006 a$ & $480.73 \pm 0.93 a$ & $0.88 \pm 0.06 a$ & $0.19 \pm 0.009 a$ & $4.96 \pm 0.06 a$ & $0.14 \pm 0.001 \mathrm{a}$ & $13.9 \pm 0.24 a$ \\
\hline $9 \mathrm{NC}$ & $7.10 \pm 0.17 d$ & $5.40 \pm 0.006 \mathrm{~b}$ & $487.23 \pm 0.25 b$ & $1.42 \pm 0.11 \mathrm{c}$ & $0.18 \pm 0.001 \mathrm{a}$ & $1.76 \pm 0.06 \mathrm{~d}$ & $0.80 \pm 0.002 \mathrm{~d}$ & $7.52 \pm 0.02 \mathrm{~d}$ \\
\hline $10 \mathrm{C}$ & $24.66 \pm 0.28 \mathrm{a}$ & $6.61 \pm 0.05 a$ & $561.30 \pm 0.36 a$ & $1.64 \pm 0.03 a$ & $0.02 \pm 0.001 a$ & $27.43 \pm 0.08 \mathrm{a}$ & $0.09 \pm 0.003 a$ & $1.36 \pm 0.05 a$ \\
\hline $10 \mathrm{NC}$ & $31.03 \pm 0.23 \mathrm{~d}$ & $7.22 \pm 0.02 \mathrm{c}$ & $529.26 \pm 0.23 \mathrm{c}$ & $5.43 \pm 0.14 \mathrm{~d}$ & $0.02 \pm 0.002 \mathrm{a}$ & $8.23 \pm 0.02 \mathrm{~d}$ & $0.44 \pm 0.006 \mathrm{~d}$ & $1.35 \pm 0.02 \mathrm{a}$ \\
\hline $11 \mathrm{C}$ & $12.96 \pm 0.28 \mathrm{a}$ & $6.73 \pm 0.006 a$ & $556.10 \pm 0.30 a$ & $1.18 \pm 0.02 \mathrm{a}$ & $0.41 \pm 0.04 a$ & $10.11 \pm 0.07 a$ & $0.13 \pm 0.004 a$ & $5.77 \pm 0.13 a$ \\
\hline $11 \mathrm{NC}$ & $14.33 \pm 0.57 \mathrm{c}$ & $6.76 \pm 0.01 \mathrm{a}$ & $537.96 \pm 0.25 \mathrm{c}$ & $3.15 \pm 0.29 \mathrm{~d}$ & $0.78 \pm 0.01 \mathrm{c}$ & $10.06 \pm 0.09 b$ & $0.15 \pm 0.001 \mathrm{~b}$ & $1.09 \pm 0.02 \mathrm{~d}$ \\
\hline $12 \mathrm{C}$ & $5.80 \pm 0.17 a$ & $4.74 \pm 0.02 a$ & $559.36 \pm 0.32 a$ & $0.91 \pm 0.05 a$ & $0.03 \pm 0.004 a$ & $21.90 \pm 0.02 a$ & $0.09 \pm 0.001 \mathrm{a}$ & $2.04 \pm 0.03 a$ \\
\hline $12 \mathrm{NC}$ & $10.40 \pm 0.17 \mathrm{~d}$ & $6.25 \pm 0.03 \mathrm{~d}$ & $542.90 \pm 2.95 b$ & $1.80 \pm 0.13 \mathrm{~d}$ & $4.94 \pm 0.08 \mathrm{~d}$ & $6.75 \pm 0.05 \mathrm{~d}$ & $0.10 \pm 0.001 \mathrm{a}$ & $1.68 \pm 0.008 \mathrm{c}$ \\
\hline $13 \mathrm{C}$ & $5.20 \pm 0.17 a$ & $4.18 \pm 0.05 a$ & $551.30 \pm 0.30 a$ & $0.98 \pm 0.07 a$ & $0.14 \pm 0.04 a$ & $2.99 \pm 0.03 a$ & $0.09 \pm 0.001 \mathrm{a}$ & $2.64 \pm 0.09 \mathrm{a}$ \\
\hline $13 \mathrm{NC}$ & $8.86 \pm 0.11 \mathrm{~d}$ & $5.64 \pm 0.06 \mathrm{~d}$ & $545.20 \pm 0.40 \mathrm{a}$ & $1.23 \pm 0.08 \mathrm{c}$ & $0.27 \pm 0.03 \mathrm{c}$ & $2.20 \pm 0.05 \mathrm{c}$ & $0.13 \pm 0.002 b$ & $1.33 \pm 0.008 \mathrm{~d}$ \\
\hline $14 \mathrm{C}$ & $6.50 \pm 0.10 \mathrm{a}$ & $4.85 \pm 0.03 a$ & $523.43 \pm 0.23 a$ & $2.69 \pm 0.19 \mathrm{a}$ & $0.01 \pm 0.001 a$ & $10.22 \pm 0.12 \mathrm{a}$ & $0.08 \pm 0.002 a$ & $3.09 \pm 0.10 \mathrm{a}$ \\
\hline $14 \mathrm{NC}$ & $9.30 \pm 0.20 \mathrm{~d}$ & $5.27 \pm 0.01 \mathrm{c}$ & $519.96 \pm 0.25 \mathrm{a}$ & $3.63 \pm 0.14 \mathrm{~d}$ & $0.02 \pm 0.002 \mathrm{a}$ & $9.05 \pm 0.03 \mathrm{c}$ & $0.09 \pm 0.001 \mathrm{a}$ & $1.74 \pm 0.38 \mathrm{~d}$ \\
\hline $15 \mathrm{C}$ & $10.86 \pm 0.11 \mathrm{a}$ & $5.58 \pm 0.06 a$ & $503.90 \pm 0.20 \mathrm{a}$ & $0.97 \pm 0.06 a$ & $0.05 \pm 0.01 a$ & $77.17 \pm 0.14 a$ & $0.08 \pm 0.007 a$ & $6.83 \pm 0.19 \mathrm{a}$ \\
\hline $15 \mathrm{NC}$ & $12.50 \pm 0.17 \mathrm{c}$ & $5.76 \pm 0.01 b$ & $493.80 \pm 0.20 b$ & $1.59 \pm 0.12 \mathrm{~d}$ & $3.39 \pm 0.06 \mathrm{~d}$ & $10.12 \pm 0.07 \mathrm{~d}$ & $0.09 \pm 0.004 a$ & $0.60 \pm 0.007 \mathrm{~d}$ \\
\hline $16 \mathrm{C}$ & $12.80 \pm 0.10 \mathrm{a}$ & $5.58 \pm 0.11 \mathrm{a}$ & $488.20 \pm 0.20 a$ & $1.25 \pm 0.05 a$ & $0.22 \pm 0.01 a$ & $32.98 \pm .27 a$ & $0.09 \pm 0.001 \mathrm{a}$ & $1.04 \pm 0.02 a$ \\
\hline $16 \mathrm{NC}$ & $19.30 \pm 0.17 \mathrm{~d}$ & $7.39 \pm 0.02 \mathrm{~d}$ & $446.16 \pm 0.47 \mathrm{c}$ & $5.80 \pm 0.43 d$ & $0.28 \pm 0.02 b$ & $13.82 \pm 0.5 \mathrm{~d}$ & $0.13 \pm 0.004 \mathrm{c}$ & $1.01 \pm 0.02 \mathrm{a}$ \\
\hline
\end{tabular}

$\mathrm{C}$ - cultivated soils (in bold), $\mathrm{NC}$ - non-cultivated soils (control). The different letter indicate significant letters between $\mathrm{C}$ and $\mathrm{NC}$ $(\mathrm{p}<0.05)$. 
of decrease of soil moisture, $\mathrm{pH}, \mathrm{TC}, \mathrm{N}-\mathrm{NH}_{4}{ }_{4}, \mathrm{~N}^{-\mathrm{NO}_{2}}$. Among investigated factors $\mathrm{Eh}, \mathrm{N}_{-} \mathrm{NO}_{3}{ }^{-}$and $\mathrm{P}_{-} \mathrm{PO}_{4}{ }^{3-}$ displayed higher values in $\mathrm{C}$ than in $\mathrm{NC}$ soils.

Generally, $\mathrm{pH}$ of majority of cultivatede soils was in the acidic range (4.66-5.96), whereas $\mathrm{pH}$ values close to neutral (6.73-6.98) were noted only in relation to four representatives of $\mathrm{C}$ soils (Table 2). In each experiment variant, the $\mathrm{pH}$ values of control soils were higher than those in cultivated soils. Cultivated soils were also characterized by lower moisture content $(5.2-24.7 \%)$ than control soils (7.1-31.03\%). Likewise, TC content was lowered in C variant $(0.8-2.7 \%)$ in comparison to $\mathrm{NC}$ soils $(1.4-5.8 \%)$. Dominant form of nitrogen was $\mathrm{N}^{-\mathrm{NO}_{3}}$, which in $\mathrm{C}$ variant was remarkably higher than in $\mathrm{NC}$ ranged from 2.99 to 77.17 , and $1.68-13.82 \mu \mathrm{g} \mathrm{g}^{-1} \mathrm{~d} . \mathrm{m}$, respectively. The second most abundant form of nitrogen in terms of quantity was $\mathrm{N}_{-} \mathrm{NH}_{4}{ }^{+}$with the amount of 0.01-0.43 $\mu \mathrm{g} \mathrm{g}{ }^{-1} \mathrm{~d} . \mathrm{m}$. in relation to $\mathrm{C}$ soils and $0.02-4.94 \mu \mathrm{g} \mathrm{g}^{-1} \mathrm{~d}$.m. in the $\mathrm{NC}$ soils. The least representative form of nitrogen was $\mathrm{N}^{-\mathrm{NO}_{2}}{ }^{-}$, at relatively low concentrations of $0.04-0.14$ and $0.09-0.87 \mu \mathrm{g}$ $\mathrm{g}^{-1}$ d.m. in $\mathrm{C}$ and $\mathrm{NC}$ soils, respectively.

To confirm taxonomic diversity in studied samples, a DGGE analysis was performed. This allowed for the use of CCA to determine differences, but also to assess the impact of the factors determining diversity.

Cluster analysis of DGGE profiles of $\mathrm{C}$ and $\mathrm{NC}$ soils by UPGMA demonstrated the separation of bacterial communities between cultivated and control soils bacterial communities (Fig. 1, Table 3). Generally larger numbers of OTUs (65) in NC soils were noted compared to C soils
(47 OTUs). This implies that in $\mathrm{C}$ samples subjected to agricultural treatments the number of dominant OTUs is lower by nearly $30 \%$ with reference to non-cultivated sites. Among cultivated soils the smallest number of OTUs (17) was noted in Albic Luvisols under oat crop type (1C), whereas the largest (28 OTUs) in Haplic Luvisols under strawberries (9C) was estimated. Control sites characterized by the largest numbers of OTUs were as follows: Mollic Gleysol under 30 year old pine woods (11NC) and Haplic Luvisol under 20 years old meadow mowed once a year (14NC), where 30 OTUs were found. Rendzina Leptosol under old meadow mowed once a year $(16 \mathrm{NC})$ was characterized by 29 OTUs. In contrast, the lowest number of OTUs (15) was noted in Haplic Luvisol under 15 years old meadow (13NC) and in Haplic Luvisol (9NC). When comparing $\mathrm{C}$ and $\mathrm{NC}$ sites it was noticed that agriculturally exploited Albic Luvisols (1C) had the same numbers of OTUs (17) as its control (1NC). The same number of OTUs (18) also appeared in Mollic Gleysol (12C, 12NC). Among Haplic Luvisols, which were the most widely represented (4 soil samples), OTU numbers ranged from 18 to 28 in arable soils, and from 15 to 30 in controls. However, the sheer number of OTUs do not necessary imply about soil biodiversity, as arable soils were also classified by increasing diversity (Table 3), expressed as Shannon-Weaver index (H'), Simpson index of diversity (D) and dominance index (1/D). Presented comparative biodiversity along a gradient of cultivated soils clearly demonstrated that higher biodiversity $\left(\mathrm{H}^{\prime}=1.60\right)$ was found in soils $(1 \mathrm{C}, 4 \mathrm{C}$, $5 \mathrm{C}, 8 \mathrm{C}, 12 \mathrm{C}, 14 \mathrm{C})$ with low OTUs (17-18), whilst lower

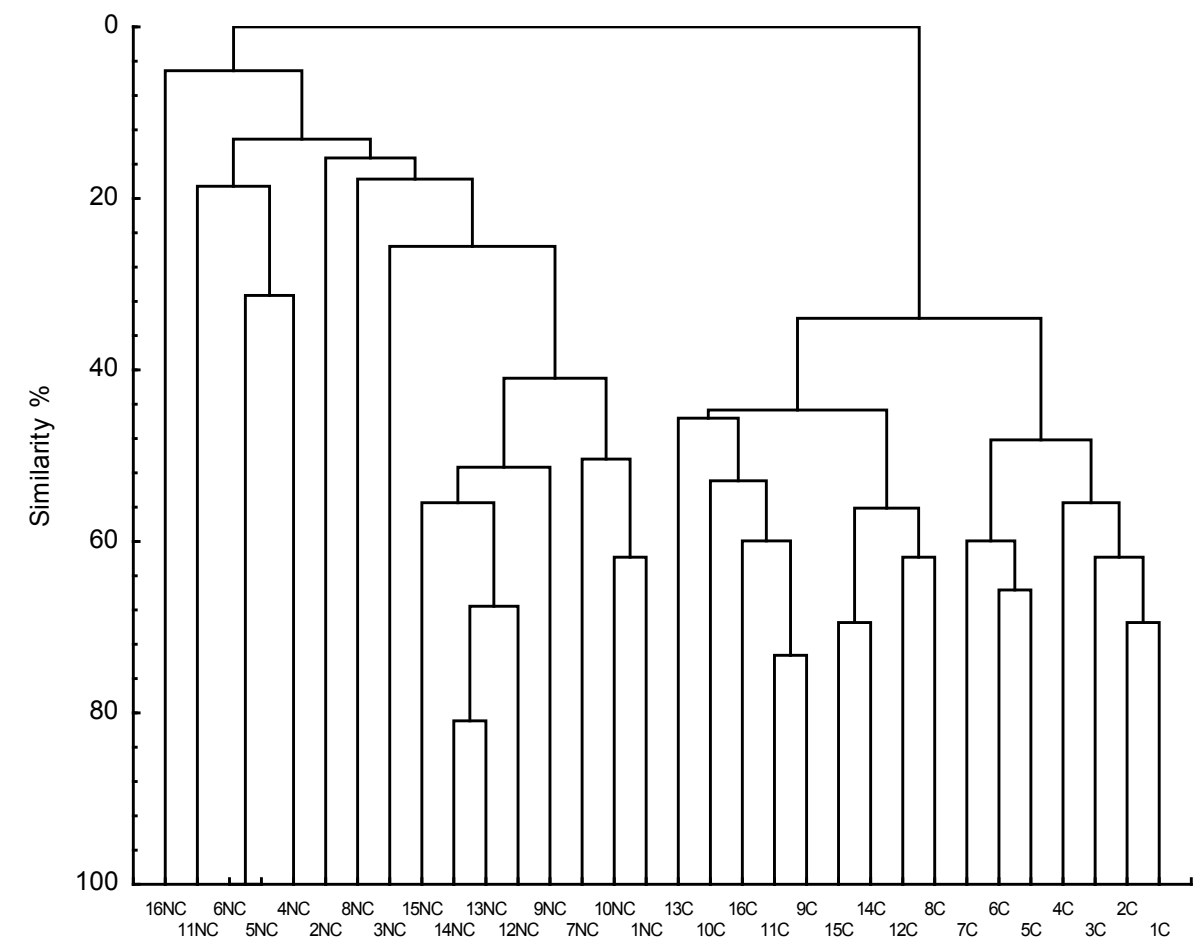

Fig. 1. Cluster analysis by UPGMA similarity of DGGE banding patterns between soil samples (NC - non-cultivated, C - cultivated). The number before $\mathrm{N}$ a NC indicates the soil sample number. 
T a b l e 3. Comparative biodiversity along a gradient of cultivated soils

\begin{tabular}{|c|c|c|c|c|c|c|c|c|c|c|}
\hline Soil type & $\begin{array}{c}\text { Non- } \\
\text { cultivated } \\
\text { soils } \\
\end{array}$ & $\mathrm{H}^{\prime}$ & $\mathrm{D}$ & $1 / \mathrm{D}$ & $\mathrm{S}$ & $\begin{array}{l}\text { Cultivated } \\
\text { soils }\end{array}$ & $H^{\prime}$ & $\mathrm{D}$ & $1 / \mathrm{D}$ & $\mathrm{S}$ \\
\hline Haplic Luvisols & 9 & 1.47 & 0.049 & 20.41 & 15 & 9 & 1.34 & 0.045 & 22.39 & 28 \\
\hline Rendzina Leptosol & 16 & 1.56 & 0.052 & 19.18 & 29 & 16 & 1.38 & 0.046 & 21.69 & 27 \\
\hline Eutric Fluvisol & 13 & 1.47 & 0.049 & 20.41 & 15 & 13 & 1.42 & 0.047 & 21.09 & 26 \\
\hline Haplic Phaezoem & 10 & 1.52 & 0.051 & 19.69 & 17 & 10 & 1.46 & 0.049 & 20.57 & 25 \\
\hline Mollic Gleysol & 11 & 1.55 & 0.052 & 19.36 & 30 & 11 & 1.46 & 0.049 & 20.57 & 25 \\
\hline Brunic Arenosols & 6 & 1.58 & 0.052 & 19.05 & 20 & 6 & 1.52 & 0.051 & 19.75 & 23 \\
\hline Albic Luvisols & 2 & 1.60 & 0.053 & 18.76 & 26 & 2 & 1.56 & 0.052 & 19.19 & 21 \\
\hline Albic Luvisols & 3 & 1.59 & 0.053 & 18.84 & 22 & 3 & 1.59 & 0.053 & 18.87 & 19 \\
\hline Haplic Luvisols & 7 & 1.50 & 0.050 & 20.02 & 16 & 7 & 1.59 & 0.053 & 18.87 & 19 \\
\hline Rendzina Leptosol & 15 & 1.58 & 0.052 & 19.05 & 20 & 15 & 1.59 & 0.053 & 18.87 & 19 \\
\hline Albic Luvisols & 1 & 1.52 & 0.051 & 19.69 & 17 & 1 & 1.60 & 0.053 & 18.78 & 17 \\
\hline Brunic Arenosols & 5 & 1.58 & 0.052 & 19.05 & 20 & 5 & 1.60 & 0.053 & 18.79 & 18 \\
\hline Eutric Histosol & 14 & 1.50 & 0.050 & 20.02 & 16 & 14 & 1.60 & 0.053 & 18.78 & 17 \\
\hline Haplic Luvisols & 8 & 1.59 & 0.053 & 18.85 & 26 & 8 & 1.60 & 0.053 & 18.79 & 18 \\
\hline Haplic Luvisols & 4 & 1.55 & 0.052 & 19.36 & 30 & 4 & 1.60 & 0.053 & 18.79 & 18 \\
\hline Mollic Gleysol & 12 & 1.54 & 0.051 & 19.43 & 18 & 12 & 1.60 & 0.053 & 18.79 & 18 \\
\hline
\end{tabular}

H'- Shannon-Weaver index of general diversity, D - Simpson index of diversity, 1/D - Simpson index of dominance, and S - number of bands for DGGE profiles.

T a b l e 4. General diversity of studied soil samples based on DGGE banding patterns

\begin{tabular}{lccc}
\hline Way of land use & H' & D & $1 / \mathrm{D}$ \\
\hline Non-cultivated (NC) & $4.87 \pm 0.03 \mathrm{a}^{*}$ & $0.30 \pm 0.001 \mathrm{a}$ & $3.38 \pm 0.05 \mathrm{a}$ \\
Cultivated (C) & $5.10 \pm 0.04 \mathrm{c}$ & $0.82 \pm 0.03 \mathrm{~d}$ & $1.22 \pm 0.4 \mathrm{~d}$ \\
\hline
\end{tabular}

Different letter indicate significant letters between $\mathrm{C}$ and $\mathrm{NC}(\mathrm{p}<0.05)$. Explanations as in Table 3.

biodiversity ( $\mathrm{H}$ ' from 1.34 to 1.38 ) have been indicated in those $(9 \mathrm{C}, 16 \mathrm{C})$ with the highest OTUs number (2528). General diversity of all studied soil samples based on DGGE patterns is shown in Tables 3 and 4.

From DGGE patterns evaluated by Shannon-Weaver index we deduce a slightly higher microbial diversity in cultivated soils $\left(\mathrm{H}^{\prime}=5.10\right)$ than in non-cultivated $\left(\mathrm{H}^{\prime}=4.87\right)$. However, Simpson index of dominance (1/D) suggests that cultivated soils contained more specifically dominant communities (18.87-21.69) compared to non-cultivated soils where phylotype richness was lowered (18.84-20.41). Simpson index computed on the entire $\mathrm{C}$ and $\mathrm{NC}$ samples reached higher level in cultivated $(0.82)$ than in control samples $(0.30)$, which confirms reduced biodiversity in arable soils. This phenomenon is also highlighted by Simpson index of dominance (1/D) calculated for all DGGE tracks, describing the number of species which in arable soils amounted $1.22 \pm 0.48$ whereas in controls was nearly threefold higher reaching $3.38 \pm 0.05$ (Table 4).

Dominant DGGE bands were cloned and sequenced. Representative sequences displayed $99-100 \%$ similarity with NCBI database as presented in Table 5 and Table 6 , for $\mathrm{C}$ and $\mathrm{NC}$ soils, respectively. Selective DGGE bands were shared among $\mathrm{C}$ and $\mathrm{NC}$ sites, for example uncultured Firmicutes bacterium clones and uncultured Acidobacteria bacterium clones. However, in most cases 
T a b I e 5. Selected species of clones obtained by PCR-DGGE in cultivated (C) soils with reference sequences in the NCBI database

\begin{tabular}{|c|c|c|c|c|}
\hline \multirow[b]{2}{*}{ Soil type (FAO) } & \multirow[b]{2}{*}{ Soil No. } & \multicolumn{3}{|c|}{ Closest match from GenBank } \\
\hline & & Match & $\begin{array}{l}\text { Sequence similarity } \\
\text { by BLAST }(\%)\end{array}$ & $\begin{array}{l}\text { GenBank accession } \\
\text { No. }\end{array}$ \\
\hline \multirow{2}{*}{ Albic Luvisol } & \multirow{2}{*}{$1-3 \mathrm{C}$} & Uncultured Bradyrhizobium sp. clone C.la-18 & $99 \%$ & JX504902.1 \\
\hline & & Phenylobacterium sp. C16-Siri106 & $99 \%$ & JX500270.1 \\
\hline \multirow{3}{*}{ Haplic Luvisol } & \multirow{3}{*}{$4 \mathrm{P}, 7-9 \mathrm{C}$} & $\begin{array}{l}\text { Uncultured Xanthomonadaceae bacterium clone } \\
\text { GASP-MB2W2_B04 }\end{array}$ & $99 \%$ & EF665380.1 \\
\hline & & $\begin{array}{l}\text { Uncultured Firmicutes bacterium clone } \\
\text { GASP-MB3W1_G09 }\end{array}$ & $99 \%$ & EF662389.1 \\
\hline & & Arthrobacter sp. PG21 & $99 \%$ & KU350608.1 \\
\hline \multirow{2}{*}{ Brunic Arenosol } & \multirow[t]{2}{*}{$5-6 \mathrm{C}$} & $\begin{array}{l}\text { Uncultured Xanthomonadaceae bacterium clone } \\
\text { GASP-MA1S2_A03 }\end{array}$ & $99 \%$ & EF665874.1 \\
\hline & & Sphingomonas sp. C0503 & $99 \%$ & JX096995.1 \\
\hline Haplic Phaeozem & $10 \mathrm{C}$ & $\begin{array}{l}\text { Uncultured Sphingobacteriales bacterium clone } \\
\text { GASP-MB2W2_D09 }\end{array}$ & $99 \%$ & EF665405.1 \\
\hline \multirow{4}{*}{ Mollic Gleysol } & \multirow{4}{*}{$11-12 \mathrm{PC}$} & $\begin{array}{l}\text { Uncultured Myxococcales bacterium clone } \\
\text { Plot4-2B08 }\end{array}$ & $100 \%$ & EU449592.1 \\
\hline & & Mucilaginibacter sp. L356 & $100 \%$ & KR181805.1 \\
\hline & & $\begin{array}{l}\text { Uncultured Acidobacteriales bacterium clone } \\
\text { E2006TS6.39 }\end{array}$ & $99 \%$ & GU983355.1 \\
\hline & & Rhodanobacter sp. T2-YC6778 & $99 \%$ & GQ369046.1 \\
\hline \multirow{4}{*}{ Eutric Fluvisol } & \multirow{4}{*}{$13 \mathrm{C}$} & Rhodanobacter sp. GR14-4 & $99 \%$ & KF441592.1 \\
\hline & & Rhodanobacter sp. A2-61 & $99 \%$ & FJ821729.1 \\
\hline & & $\begin{array}{l}\text { Uncultured Gammaproteobacteria clone } \\
\text { GC0AA3ZG11PP1 }\end{array}$ & $99 \%$ & JQ919685.1 \\
\hline & & Mucilaginibacter sp. UR6-11 & $100 \%$ & KF900219.1 \\
\hline \multirow{3}{*}{ Eutric Histosol } & \multirow{3}{*}{$14 \mathrm{C}$} & Uncultured bacterium clone WW1_a33 & $100 \%$ & GQ264172.1 \\
\hline & & Uncultured bacterium clone Hswb-15 & $100 \%$ & GU113036.1 \\
\hline & & $\begin{array}{l}\text { Uncultured Gammaproteobacteria clone } \\
\text { GC0AA4ZE09PP1 }\end{array}$ & $99 \%$ & JQ919693.1 \\
\hline $\begin{array}{l}\text { Rendzina } \\
\text { Leptosol }\end{array}$ & $15-16 \mathrm{C}$ & $\begin{array}{l}\text { Uncultured Acidobacteria bacterium clone } \\
\text { AEW } 08449\end{array}$ & $100 \%$ & HQ598290.1 \\
\hline
\end{tabular}

we noted differences between $\mathrm{C}$ and $\mathrm{NC}$ microbial communities composition. In agricultural soils (Table 5) uncultured representatives belonging to Myxococcales, Mucilaginibacter sp. L356 and Mucilaginibacter sp. UR6-11 were detected with $100 \%$ sequence similarity to the NCBI database. Others, displaying $99 \%$ similarity were mostly represented by uncultured clones of Bradyrhizobium sp., Xanthomonadaceae, Gammaproteo- bacteria, Sphingomonas sp., Myxococcales, Rhodanobacter sp., Mucilaginibacter sp. and Arthrobacter sp. With respect to control soils, $100 \%$ similarity with NCBI database was found in uncultured representatives of Acidobacteriaceae and Firmicutes bacterium clones (Table 6). Similarly, with $99 \%$ sequence similarity presence of uncultured Hyphomicrobiaceae, Gemmatimonadetes, Caulobacterales and Alphaproteobacterium bacterium clones were detec- 
T a b l e 6. Selected species of clones obtained by PCR-DGGE in control (NC) soils with reference sequences in the NCBI database

\begin{tabular}{|c|c|c|c|c|}
\hline \multirow[b]{2}{*}{ Soil type (FAO) } & \multirow[b]{2}{*}{ Soil No. } & \multicolumn{3}{|l|}{ Closest match from GenBank } \\
\hline & & Match & $\begin{array}{l}\text { Sequence similarity } \\
\text { by BLAST }(\%)\end{array}$ & $\begin{array}{c}\text { GenBank accession } \\
\text { No. }\end{array}$ \\
\hline \multirow{3}{*}{ Albic Luvisol } & \multirow{3}{*}{$1-3 \mathrm{NC}$} & $\begin{array}{l}\text { Uncultured Firmicutes bacterium clone } \\
\text { GASP-MB2S2_C02 }\end{array}$ & $99 \%$ & EF665117.1 \\
\hline & & $\begin{array}{l}\text { Uncultured Hyphomicrobiaceae } \\
\text { bacterium clone Elev_16S_1585 }\end{array}$ & $99 \%$ & EF020154.1 \\
\hline & & $\begin{array}{l}\text { Uncultured Acidobacteria bacterium } \\
\text { clone AEW_08_408 }\end{array}$ & $99 \%$ & HQ598261.1 \\
\hline \multirow{3}{*}{ Haplic Luvisol } & \multirow{3}{*}{$4 \mathrm{NC}, 7-9 \mathrm{NC}$} & $\begin{array}{l}\text { Uncultured Acidobacteriaceae bacterium } \\
\text { clone CK-113 }\end{array}$ & $100 \%$ & KM200541.1 \\
\hline & & $\begin{array}{l}\text { Uncultured Firmicutes bacterium clone } \\
\text { GASP-MA1W2_D03 }\end{array}$ & $100 \%$ & EF662688.1 \\
\hline & & $\begin{array}{l}\text { Uncultured Hyphomicrobiaceae } \\
\text { bacterium clone Elev_16S_1697 }\end{array}$ & $99 \%$ & EF020212.1 \\
\hline \multirow{4}{*}{ Brunic Arenosol } & \multirow{4}{*}{$5-6 \mathrm{NC}$} & $\begin{array}{l}\text { Uncultured Firmicutes bacterium clone } \\
\text { GASP-MB2S1_B06 }\end{array}$ & $100 \%$ & EF665018.1 \\
\hline & & $\begin{array}{l}\text { Uncultured Caulobacterales bacterium } \\
\text { clone Plot4-G04 }\end{array}$ & $99 \%$ & EU449571.1 \\
\hline & & $\begin{array}{l}\text { Uncultured Rhodoplanes sp. partial 16S } \\
\text { rRNA gene, clone7B_09 }\end{array}$ & $99 \%$ & HE861294.1 \\
\hline & & $\begin{array}{l}\text { Uncultured Hyphomicrobiaceae } \\
\text { bacterium clone Amb_16S_918 }\end{array}$ & $99 \%$ & EF018637.1 \\
\hline \multirow[b]{2}{*}{ Haplic Phaeozem } & \multirow[b]{2}{*}{$10 \mathrm{NC}$} & Uncultured bacterium clone FCPO743 & $99 \%$ & EF516120.1 \\
\hline & & $\begin{array}{l}\text { Uncultured Hyphomicrobiaceae } \\
\text { bacterium clone Amb_16S_1248 }\end{array}$ & $99 \%$ & EF018785.1 \\
\hline \multirow{2}{*}{ Mollic Gleysol } & \multirow{2}{*}{$11-12 \mathrm{NC}$} & $\begin{array}{l}\text { Uncultured Rhodoplanes sp. clone } \\
\text { GASP-MA1W1_B04 }\end{array}$ & $99 \%$ & EF662607.1 \\
\hline & & $\begin{array}{l}\text { Uncultured bacterium isolate DGGE gel } \\
\text { band JHH-D7-1A-c35 }\end{array}$ & $99 \%$ & HM148942.1 \\
\hline \multirow{2}{*}{ Eutric Fluvisol } & \multirow{2}{*}{$13 \mathrm{NC}$} & Mesorhizobium sp. AM20-87 & $99 \%$ & KP899163.1 \\
\hline & & Uncultured bacterium clone FCPO696 & $99 \%$ & EF516451.1 \\
\hline \multirow{2}{*}{ Eutric Histosol } & \multirow{2}{*}{$14 \mathrm{NC}$} & $\begin{array}{l}\text { Uncultured forest soil bacterium clone } \\
\text { DUNssu184 }\end{array}$ & $100 \%$ & AY913390.1 \\
\hline & & $\begin{array}{l}\text { Uncultured forest soil bacterium clone } \\
\text { DUNssu053 }\end{array}$ & $99 \%$ & AY913275.1 \\
\hline \multirow{2}{*}{ Rendzina Leptosol } & \multirow{2}{*}{$15-16 \mathrm{NC}$} & $\begin{array}{l}\text { Uncultured Alphaproteobacterium clone } \\
\text { GASP-WC1S3_B03 }\end{array}$ & $99 \%$ & EF074556.1 \\
\hline & & $\begin{array}{l}\text { Uncultured Alphaproteobacterium clone } \\
\text { GASP-MB3W2 A04 }\end{array}$ & $99 \%$ & EF665890.1 \\
\hline
\end{tabular}


ted. Furthermore, in NC soils uncultured Rhodoplanes sp., Mesorhizobium sp. and forest soil bacterium clones were also identified.

Effect of agricultural practices on soil biodiversity reduction was also determined by performing the principal component analysis. DGGE profiles revealed clear differences in microbial diversity of the soil samples (Fig. 2). Cultivated soil samples demonstrated increased affinity to each other by forming a clear cluster, in contrast to controls where samples $(3 \mathrm{NC}, 4 \mathrm{NC}, 6 \mathrm{NC}, 11 \mathrm{NC})$ differed from samples in other positions. Principal component analysis also pointed to a greater similarity of $\mathrm{C}$ soils within the group with less resemblance to $\mathrm{NC}$ sites.

Chemical factors effect on investigated soil types ( $\mathrm{C}$ and NC) based on DGGE patterns are presented in Fig. 3. The correspondence analysis has shown that the overall variability index (Total Inertia) makes it possible to apply the linear fit. The PCA analysis revealed a significant variability in the samples. This highlights the need for conducting further analyses in the CCA system relative to the background. Our results suggest that $\mathrm{Eh}$ and $\mathrm{N}_{-} \mathrm{NO}_{3}{ }^{-}$are the critical factors controlling microbial communities in arable soils, particularly with regards to Haplic Luvisols (4C, 9C), Mollic Gleysols (11C, 12C) and Rendzina Leptosol (15C). Microbial community from control sites grouped in the right bottom quadrant $(1 \mathrm{NC}, 4 \mathrm{NC}, 7 \mathrm{NC}, 8 \mathrm{NC}, 10 \mathrm{NC}$, $14 \mathrm{NC}, 16 \mathrm{NC}$ ) depended on soil moisture and TC content. On the other hand, biogenic forms of phosphorus $\left(\mathrm{P}^{-} \mathrm{PO}_{4}{ }^{3}\right)$, nitrogen $\left(\mathrm{N}_{-} \mathrm{NO}_{2}{ }^{-}, \mathrm{N}_{-} \mathrm{NH}_{4}^{+}\right)$and $\mathrm{pH}$, affecting microbial community from non-cultivated soils, clustered in the top right quadrant $(3 \mathrm{NC}, 11 \mathrm{NC}, 12 \mathrm{NC})$. The Monte Carlo Permutation test revealed that moisture, $\mathrm{TC}$ and $\mathrm{pH}$ were the three important factors responsible for effects at a statistically significant level.

\section{DISCUSSION}

The fact that soil agricultural treatments strongly modify soil chemical parameters was reported by Girvan et al. (2003), Lopes et al. (2011) and Wolińska et al. (2014). Also decline of $\mathrm{pH}$ toward acidic conditions as an effect of agricultural practices and depletion of TC in arable soils was earlier indicated (Bossio et al., 2005; Wolińska et al., 2014). These observations are consistent with results presented in the current study, where decrease of $\mathrm{pH}$ and TC content was noted in $\mathrm{C}$ soils. It was stated that vegetation type and carbon concentration may influence microbial community composition at local scales, whereas soil $\mathrm{pH}$ is a better predictor of a community structure at the continental scale (Fierer and Jackson, 2006). Observed increase in Eh in $\mathrm{C}$ soils was linked to the fact that agricultural practices, such as ploughing, contribute favourably to oxygen enhancement in the soil surface, whereas growth of $\mathrm{N}^{-\mathrm{NO}_{3}}{ }_{3}^{-}$ and $\mathrm{P}_{-} \mathrm{PO}_{4}{ }^{3-}$ may be caused by systematically fertilization practices in arable soils. Domination of nitrate nitrogen in

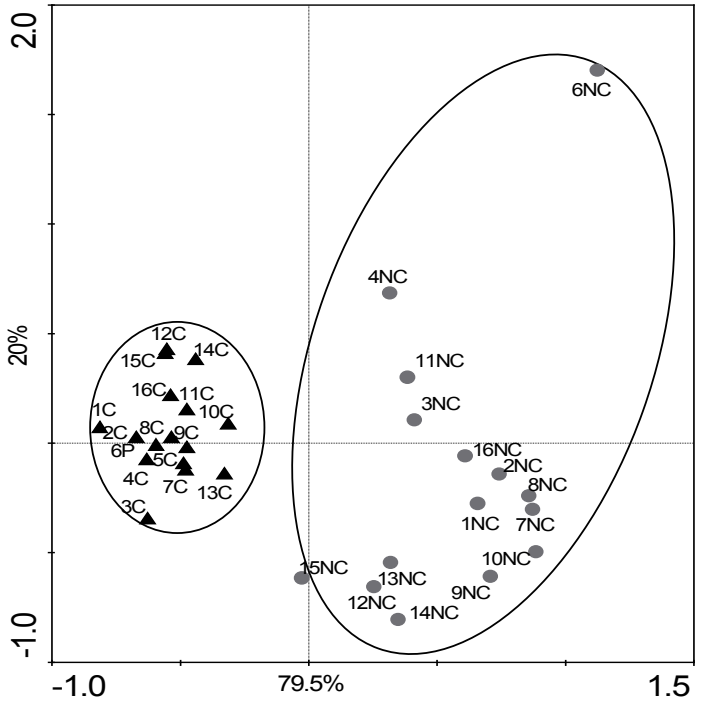

Fig. 2. Principal components analysis (PCA) of DGGE band patterns. Numbers beside the symbols indicate the soil samples number, circle - non-cultivated soils (NC), triangles - cultivated soils $(\mathrm{C})$.

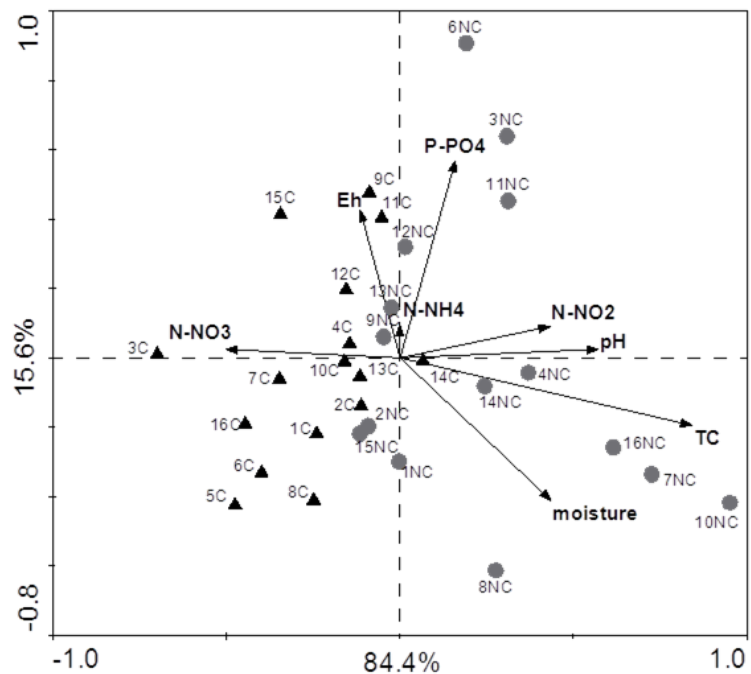

Fig. 3. Canonical correspondence analysis (CCA) for the positions and chemical factors based on DGGE profiles. Numbers beside the symbols indicate the soil samples number, circle - noncultivated soils (NC), triangles - cultivated soils (C).

agricultural soils especially during the spring season can be explained by agricultural practices such as fertilization, and high soil temperature that stimulate aerobic $\mathrm{N}$ transformation, resulting in the nitrification of of $\mathrm{N}^{-\mathrm{NH}_{4}}{ }^{+}$(Campos, 2010). Furthermore, one extremely important observation seems to be the marked reduction of $\mathrm{N}^{-\mathrm{NO}_{2}}{ }^{-}$concentration in all cultivated soil which suggests that microbiological processes associated with nitrogen compounds in cultivated soils may prevent the accumulation of $\mathrm{N}^{-\mathrm{NO}_{2}}$. Similarly, a decrease in $\mathrm{N}^{-\mathrm{NH}_{4}}{ }^{+}$noted in cultivated soils might suggest on intensive nitrification processes in $\mathrm{C}$ soils. It should be mentioned that we collected the soil material prior to 
fertilizer application. Thus, noted concentration range for $\mathrm{N}-\mathrm{NH}_{4}{ }^{+}$resulted from its pool that remained in the soil after winter time. Our data are consistent with the findings of Avrahami et al. (2003) who observed that even after the direct fertilization of soil with $\mathrm{N}-\mathrm{NH}_{4}{ }^{+}$a decrease of ammonium and increase in nitrate concentrations occurred. This phenomenon was favoured by intermediate air temperatures, i.e. $15-25^{\circ} \mathrm{C}$, whereas during soil sampling in spring 2014 the air temperature was in the range of $20-22^{\circ} \mathrm{C}$.

An impact of land management practices on bacterial diversity structure still remains unrecognised. It has been suggested that agriculture creates highly selective and homogeneous environments that reduce bacterial diversity, particularly Rhizobium populations (Palmer and Young, 2000). Some studies were performed in order to report on the differences in microbial diversity between soils under conventional and organic farming systems (Bossio et al., 2005; Kuffner et al., 2004; Lopes et al., 2011). In that context, the present study is the first one that compared the bacterial community in cultivated and non-cultivated Polish soils, represented by seven types and sixteen soil units. We found that, differentiation between cultivated and non-cultivated soils on the level of chemical features is clearly a consequence of different soil management practices and this was also the reason for the diversification in the microbial community structure. In our study landuse management seemed to be a major determinant of the bacterial communities, because more than the soil type it determined the clustering into groups (Fig. 1) and showed clear differences in microbial composition between $\mathrm{C}$ and $\mathrm{NC}$ sites (Tables 5 and 6). This dependency is well shown based on uncultured Hyphomicrobiaceae bacterium clones whose presence (99-100\% similarity) has been demonstrated in Albic Luvisols, Haplic Luvisols, Brunic Arenosols and Haplic Phaeozem (Table 6). Also, representatives of Xanthomonadaceae bacterium clones were common across Albic Luvisols and Brunic Arenosols (Table 5). In contrast, Gammaproteobacteria were noted both in Eutric Histosol and Eutric Fluvisols (Table 5). Similarly, the presence of Rhodanobacter sp. was stated both in Mollic Gleysol and Eutric Fluvisol, whereas Mucilinibacter sp. were common across Eutric Histosol and Mollic Gleysol (Table 5). Bossio et al. (2005) confirmed that different management practices affected both microbial community composition and function. In contrast, Girvan et al. (2003) suggested that it is likely that the total bacterial community compositions have been determined primarily by the underlying soil chemistry and structure rather than by the different management practices or cropping regimens at these sites. Additionally, soil has been shown to have an immense capacity for diversity and therefore a large buffering capacity before the results of management practices will likely affect the dominant members of the community (Girvan et al., 2003). In any case, it should be emphasized that the longer-term impacts of management practices may be much more significant, than what was shown in the current study.

The analysis of DGGE profiles based on the diversity of $16 \mathrm{~S}$ rRNA bacterial gene clearly demonstrated two separate clusters for $\mathrm{C}$ and $\mathrm{NC}$ soils. These findings are also confirmed by Shannon-Weaver index of geneal diversity (H'), Simpson index of diversity (D) and Simpson index of dominance (1/D). This diversity indices clearly point to biodiversity loss in a systematical and longterm exploited arable soils, regardless of the soil type. Specifically, this fact has been the most strongly highlighted by Simpson index of dominance, where its value pointed for $\mathrm{NC}$ sites threefold exceeding the 1/D level estimated in C soils by a factor of 3. Lopes et al. (2011) reported Shannon-Weaver index for cultivated paddy Portugal soils under conventional system on the level of 1.26 , meanwhile in our study H' achieved values of 1.34-1.60 and 1.47-1.560, for cultiated and control soils, respectively. Shao-Qiang et al. (2012) indicated that in Chinese alluvial soil under ricewheat cropping system the highest genetic biodiversity $\left(H^{\prime}=3.061\right)$ characterized fertilized soils, while the poorest biodiversity $\left(H^{\prime}=2.692\right)$ was found in control (non fertilized) soils. These results suggest that investigated soils from the Lublin region have higher biodiversity than paddy soils from Portugal but lower than alluvial China soils.

PCA analysis also indicated a clustering among the $\mathrm{C}$ soils that were associated with soil cultivation and $\mathrm{NC}$ soils under any cultivation system for 15-30 years. This might indirectly confirm the impact of agricultural management on the bacterial communities in the soils. Apart from human agricultural management, soil microbial community is dependent on chemical features of the site. Our study demonstrated that moisture, TC and $\mathrm{pH}$ affected on microbial community in control soils, while Eh and $\mathrm{N}-\mathrm{NO}_{3}{ }^{-}$ influenced microorganisms in cultivated soils. It is worth mentioning that moisture in control sites was by $20-30 \%$ higher than in agricultural soils. TC in $\mathrm{NC}$ variant reached on average $70 \%$ higher level than in $\mathrm{C}$ soils, whereas $\mathrm{pH}$ in controls was close to neutral in contrast to acidic conditions noted in arable soils. All these factors are important for microbial activities. Similarly, changes in soil moisture status is known to affect the magnitude of biological activities, because many soil microorganisms are known to be intolerant of low moisture content (Wolińska et al., 2015). The next important, environmental factor, expressing the tendency of an environment to receive or to supply electrons in solution is The well-oxygenated soils are characterized by high values of Eh (600-800 mV), in quite well-oxygenated soils Eh $\sim 500-600 \mathrm{mV}$, whereas in anaerobic conditions a decline in Eh below $300 \mathrm{mV}$ or even to lower values was observed (Pett-Ridge and Firestone, 2005; Wolińska et al., 2014). It is well known, that Eh plays a crucial role in regulating microbial activity as well as community structure (Pett-Ridge and Firestone, 2005). In terms of the soils 
investigated in the current study, Eh strongly influenced on microbial community in C soils (Fig. 3), where it amounted from 403 to $561 \mathrm{mV}$, whereas reached lower values (396$545 \mathrm{mV}$ ) in $\mathrm{NC}$ variant (Table 2). Also amounts of $\mathrm{NO}_{3}-\mathrm{N}$ and $\mathrm{PO}_{4}-\mathrm{P}$ were higher in agricultural soils, which resulted from systematically fertilization of $\mathrm{C}$ sites (at least from 25 years, since 1991) and affected on microbial community in arable soils. In our study, limitation of water, lower content of TC, higher level of Eh and $\mathrm{NO}_{3}-\mathrm{N}$ concentrations and acidic $\mathrm{pH}$ noted in arable soils seemed to be the important factors responsible for the clear differences between the $\mathrm{C}$ and NC soil samples, with regard to dominant OTUs. This knowledge can be instructive for the optimal land-use management practices and enhance sustainable agriculture.

\section{CONCLUSIONS}

1. The biodiversity of microbial communities is different in the areas under cultivation than in non-cultivated soils.

2. Human agricultural activity and soil chemical parameters are important, selective factors for bacterial selection in arable soils.

3. Larger numbers of operational taxonomic units were found in control soils compared to agricultural soils, which indicates an almost 30\% reduction in dominant bacterial operational taxonomic units. These is additionally confirmed by Simpson dominance index of 1.22, expressing the 'abundance weighted true diversity', whereas in the controls this index reached 3.38 which is by almost a factor of 3 higher.

4. Agricultural soil usage is the factor crucial for biodiversity structure

5. The most important key chemical factors associated with microbial community compositions turn out to be soil moisture, $\mathrm{pH}, \mathrm{TC}, \mathrm{Eh} \mathrm{N}-\mathrm{NO}_{3}{ }^{-}$and $\mathrm{P}_{-} \mathrm{PO}_{4}{ }^{3-}$, but, their impact depended on the land-use management practices.

6. In cultivated soils the most critical for microbial community factors are Eh and $\mathrm{NO}_{3}-\mathrm{N}$, whereas moisture, $\mathrm{pH}$, $\mathrm{TC}$ and $\mathrm{P}-\mathrm{PO}_{4}^{3-}$-seemed important in non-cultivated sites.

\section{ACKNOWLEDGEMENTS}

The Authors are also grateful to our technical assistant Andrzej Górski for his contribution to the field trips and to Marek Pazur from the Institute of Agrophysics Polish Academy of Sciences in Lublin (Poland) for his help in precise location of soil sampling sites. The Authors are also grateful to Dr P. Misztal (University of California Berkeley, USA) for suggestions resulting in language improvement.

Conflict of interest: The Authors do not declare conflict of interest.

\section{REFERENCES}

Arias M.E., Gonzales-Perez J.A., Gonzales-Vila F.J., and Ball A.S., 2005. Soil health-a new challenge for microbiologists and chemists. Int. Microbiol., 8, 13-21.

Avrahami S., Liesack W., and Conrad R., 2003. Effects of temperature and fertilizer on activity and community structure of soil ammonia oxidizers. Environ. Microbiol., 5, 691-705.

Banach A.M., Banach K., Visser E.J.W., Stępniewska Z., Smits A.J.M., Roelofs J.G.M., and Lamers L.P.M., 2009. Effects of summer flooding on floodplain biogeochemistry in Poland; implications for increased flooding frequency. Biogeochemistry, 92, 247-262.

Bieganowski A., Witkowska-Walczak B., Gliński J., Sokołowska Z., Sławiński C., Brzezińska M., and Wlodarczyk T., 2013. Database of Polish arable mineral soils: a review. Int. Agrophys., 27, 335-350.

Bossio D.A., Girvan M.S., Verchot L., Bullimore J., Borelli T., Albrecht A., Scow K.M., Ball A.S., Pretty J.N., and Osborn A.M., 2005. Soil microbial community response to land use change in an agricultural landscape of western Kenya. Microb. Ecol., 49, 50-62.

Campos A., 2010. Response of soil inorganic nitrogen to land use and topographic position in the Cofre de Perote Vulcano (Mexico). Environ. Manag., 46, 213-224.

Casamayor E.O., Schafer H., Baneras L., Pedros-Alio C., and Muyzer G., 2000. Identification of and spatio-temporal differences between microbial assemblages from two neighbouring sulphurous lakes: comparison by microscopy and denaturing gradient gel electrophoresis. Appl. Environ. Microbiol., 66, 499-508.

Chong C.W., Tan A.G.Y., Wong R.C.S., Riddle M.J., and Tan I.K.P., 2009. DGGE fingerprinting of bacteria in soils from eight ecologically different sites around Casey Station, Antarctica. Polar. Biol., 32, 853-860.

Crump B.C. and Hobbie J.E., 2005. Synchrony and seasonality in bacterioplankton communities of two temperate rivers. Limnol. Oceanogr., 50, 1718-1729.

Fierer N. and Jackson R.B., 2006. The diversity and biogeography of soil bacterial communities. Proc. Nat. Acad. Sci., 103, 626-631.

Girvan M.S., Bullimore J., Pretty J.N., Osborn A.M., and Ball A.S., 2003. Soil type is the primary determinant of the composition of the total and active bacterial communities in arable soils. Appl. Environ. Microbiol., 69, 1800-1809.

Gliński J., Ostrowski J., Stępniewska Z., and Stępniewski W., 1991. Soil samples bank representing mineral soils of Poland (in Polish). Prob. Agrophys., 66, 5-57.

Kuffner M., Pinar G., Hace K., Handschur M., and Haslberger A.G., 2004. DGGE-fingerprinting of arable soils shows differences in microbial community structure of conventional and organic farming systems. Food, Agric. Environ., 2, 259-267.

Lopes A.R., Faria C., Prieto-Fernandez A., Trasar-Cepeda C., Manaia C.M., and Nunes O.C., 2011. Comparative study of the microbial diversity of bulk paddy soil of two rice fields subjected to organic and conventional farming. Soil Biol. Biochem., 43, 115-125. 
Lozupone C.A., Hamady M., Kelley S.T., and Knight R., 2007. Qualitative and quantitative $\beta$ diversity measures lead to different insight into factors that structure microbial communities. Appl. Environ. Microbiol., 73, 1576-1585.

Muyzer G., Brinkhoff T., Nüel U., Santegoeds C., Schäfer H., and Waver C., 1998. Denaturing gradient gel electrophoresis (DGGE) in microbial ecology. In: Molecular Microbial Ecology Manual (Eds A.D.L. Akkermans, J.D. van Elsas and F.J. de Bruijn). Kluwer Academic Publ., Dordrecht, the Netherlands.

Muyzer G., de Waal D.C., and Uitterlinden A.G., 1993. Profiling of complex microbial populations by denaturing gradient gel electrophoresis analysis of polymerase chain reaction-amplified genes coding for $16 \mathrm{~S}$ rRNA. Appl. Environ. Microbiol., 59, 695-700.

Palmer K.M. and Young J.P.W., 2000. Higher diversity of Rhizobium leguminosarum biovar viciae populations in arable soils than in grass soils. Appl. Environ. Microbiol., $66,2445-2450$.

Petersen D.G. and Dahllöf I., 2005. Improvements for comparative analysis of changes in diversity of microbial communities using internal standards in PCR-DGGE. FEMS Microbiol. Ecol., 53, 339-348.

Pett-Ridge J. and Firestone M., 2005. Redox fluctuation structures microbial communities in a wet-tropical soil. Appl. Environ. Microbiol., 71, 6998-7007.

Sambrook J., Fritsch E.F., and Maniatis T., 1989. Molecular cloning: a laboratory manual. Cold Spring Harbor Laboratory, Cold Spring Harbor, NY.

Shannon C.E. and Weaver W., 1963. The Mathematical Theory of Communication. University of Illinois Press, Urbana, IL, USA.

Shao-Qiang T., Qiang X., Zhu, L., Chen J.J., Wang Y.N., and Qin B., 2012. Analysis of the bacterial communities in lime concretion black soil upon the incorporation of crop residues. Open J. Soil Sci., 9, 312-319.
Simpson E.H., 1949. Measurement of diversity. Nature, 163, 688-688.

ter Braak C.J.F. and Šmilauer P., 2002. CANOCO reference manual and CanoDraw for Windows user's guide: software for canonical community ordination (version 4.5). Microcomputer Power, Ithaca.

Tomczyk-Żak K., Kaczanowski S., Drewniak Ł., Dmoch Ł., Skłodowska A., and Zielenkiewicz U., 2013. Bacteria diversity and arsenic mobilization in rock biofilm from an ancient gold and arsenic mine. Sci. Tot. Environ., 461, 330-340.

Torsvik T., Daae F.L., Sandaa R.A., and Ovreas L., 1998. Novel techniques for analysing microbial diversity in natural and perturbed environments. J. Biotech., 64, 53-62.

Vivas A., Moreno B., Garcia-Rodriguez S., and Benitez E., 2009. Assessing the impact of composting and vermicomposting on bacterial community size and structure, and microbial functional diversity of an olive-mill waste. Biores. Technol., 100, 1319-1326.

Wolińska A., Szafranek-Nakonieczna A., Banach A., RekoszBurlaga H., Goryluk-Salmonowicz A., Blaszczyk M., Stępniewska Z., and Górski A., 2014. Biological degradation of arable soils from Lublin region (SE Poland). Int. J. Curr. Microbiol. Appl. Sci., 3, 558-571.

Wolińska A., Stępniewska Z., and Pytlak A., 2015. The effect of environmental factors on total soil DNA content and dehydrogenase activity. Arch. Biol. Sci., 67, 493-501.

Zdanowski M.K., Żmuda-Baranowska M., Borsuk P., Świątecki A., Górniak D., Wolicka D., Jankowska K.M., and Grzesiak J., 2013. Culturable bacteria community development in postglacial soils of Ecology Glacier, King George Island, Antarctica. Polar Biol., 36, 511-527. 